\title{
Perforated duodenal ulcer in a pediatric patient with eosinophilic gastroenteritis
}

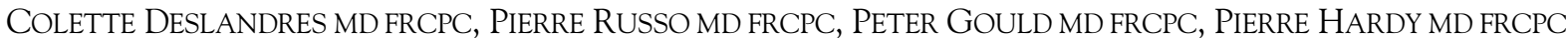

\begin{abstract}
C Deslandres, P Russo, P Gould, P Hardy. Perforated duodenal ulcer in a pediatric patient with eosinophilic gastroenteritis. Can J Gastroenterol 1997;11(3):208-212. An 11-yearold boy with eosinophilic gastroenteritis treated by an elimination diet alone presented with a perforated gastroduodenal ulcer subsequent to blunt trauma to the abdomen. Peripheral eosinophilia, chronic iron deficiency, chronic hypoalbuminemia and severe failure to thrive had been present since age 2 years. Immunological work-up revealed food allergies, documented by skin tests. A review of the literature since 1966 revealed only six other cases of perforation of the gastrointestinal tract, one of whom was also a child.
\end{abstract}

Key Words: Child, Eosinophilic gastroenteritis, Perforated duodenal ulcer

\section{Perforation d'un ulcère duodénal chez un patient atteint de gastroenteropathie éosinophilique}

RÉSUMÉ : Un garçon de 11 ans présentant une gastroenteropathie éosinophilique, et traité uniquement par un régime d'exclusion, s'est présenté avec une perforation d'un ulcère duodénal faisant suite à un traumatisme abdominal fermé. Une éosinophilie périphérique, une insuffisance chronique de fer, une hypoalbuminémie chronique et un retard de croissance sévère étaient présents depuis l'âge de 2 ans. Un bilan immunologique avait mis en évidence des allergies alimentaires documentées par des tests cutanés. Une revue de la littérature depuis 1966 a révélé seulement six autres cas de perforation du tractus gastro-intestinal, parmi lesquels, un concernait également un enfant.
$\mathrm{D}$ iffuse eosinophilic gastroenteritis (EGE) was first described by Kaijser in 1937 (1). EGE is characterized by various gastrointestinal symptoms, peripheral eosinophilia and eosinophilic infiltration of the gastrointestinal tract without granuloma formation or vasculitis (2-7). This uncommon inflammatory disorder is further characterized by tissue eosinophilia unexplained by intestinal parasitic infestations, neoplasia, vasculitis or other known causes $(8,9)$. EGE is an idiopathic disorder with a male predominance generally affecting persons between age 10 and 50 years (7). Half of the affected patients have an atopic history (10).

According to the classification of Klein et al (11), EGE may be divided into three subgroups depending on its pri- mary involvement: mucosal, muscular or serosal. Symptoms of EGE vary and include intermittent nausea, vomiting, abdominal pain, diarrhea, gastrointestinal bleeding, weight loss or stunting of growth, gastrointestinal obstruction, ascites and perforation or fistula. We present a pediatric case with EGE and an upper intestinal perforation, and a literature review of this rare complication.

\section{CASE PRESENTATION}

The male patient was born at 37 weeks gestation after an uncomplicated pregnancy. Birth weight was $2.4 \mathrm{~kg}$ (less than fifth percentile). Both parents were Chinese. His mother was $150 \mathrm{~cm}$ tall and father was $155 \mathrm{~cm}$ tall. Family history was

Divisions of Gastroenterology and Nutrition, and Pathology, Hôpital Ste-Justine and Montreal Children's Hospital, Université de Montréal; and McGill University, Montreal, Quebec

Correspondence: Dr C Deslandres, Division of Gastroenterology-Nutrition, Hôpital Ste-Justine, 3175 côte Ste-Catherine, Montréal, Québec H3T 1C5. Telephone 514-345-4626, fax 514-345-4801

Received for publication August 8, 1995. Accepted June 6, 1996 


\section{TABLE 1}

Complete blood cell counts and differential of the presented patient

\begin{tabular}{|c|c|c|c|c|c|c|c|c|c|}
\hline $\begin{array}{l}\text { Age } \\
\text { (years/months) }\end{array}$ & $\begin{array}{c}\text { WBC } \\
\left(\times 10^{6} / L\right)\end{array}$ & $\begin{array}{l}\text { Hemoglobin } \\
\text { (g/L) }\end{array}$ & $\begin{array}{c}\text { MCV } \\
(\mathrm{fL})\end{array}$ & $\begin{array}{c}\text { Eosinophils } \\
\left(\times 10^{6} / \mathrm{L}\right)\end{array}$ & $\begin{array}{c}\text { ESR } \\
(\mathrm{mm} / \mathrm{h})\end{array}$ & $\begin{array}{c}\text { BUN (mg/dL) } \\
\text { normal 6-20 }\end{array}$ & $\begin{array}{l}\text { SGOT (U/L) } \\
\text { normal <33 }\end{array}$ & $\begin{array}{l}\text { SGPT (U/L) } \\
\text { normal <26 }\end{array}$ & $\begin{array}{c}\text { Iron }(\mu \mathrm{g} / \mathrm{dL}) \\
\text { normal } 50-180\end{array}$ \\
\hline $2 / 3$ & 15,000 & 81 & 64 & 1800 & & & & & \\
\hline $3 / 5$ & 9300 & 75 & 66 & 186 & & & & & \\
\hline $4 / 7$ & 7700 & 107 & 85 & 154 & & & & & \\
\hline $9 / 4$ & 11,500 & 94 & 66.7 & 345 & 6 & 19 & 22 & 9 & 35 \\
\hline $12 / 8$ & 7000 & 85 & 70.2 & 630 & & & & & \\
\hline
\end{tabular}

${ }^{*}$ At age 11 years 9 months the patient was operated for perforated ulcer and received a blood transfusion; ${ }^{\dagger}$ One week postoperation. BUN Blood urea nitrogen; ESR Erythrocyte sedimentation rate; MCV Mean cell volume; SGOT Serum glutamic-pyruvic transaminase; SGPT Serum glutamic-oxaloacetic transaminase; WBC White blood cell count

noncontributory. The patient was noted to be anemic at the time of an elective inguinal hernia repair around age 1.5 years at another institution. He was subsequently admitted to the authors' institution for evaluation of a microcytic anemic (hemoglobin $74 \mathrm{~g} / \mathrm{L}$, mean cell volume $62 \mathrm{fL}$ ) and hypoalbuminemia $(27 \mathrm{~g} / \mathrm{L})$ at age 28 months. White blood cell count was increased to $15,000 \times 10^{6} / \mathrm{L}$ with peripheral eosinophilia (12\%) (Table 1). Both height and weight were below the 10th centile. Review of systems revealed bilateral periorbital edema upon awakening. Occult blood loss in his stools had been noted on an out-patient basis. A clinical diagnosis of milk protein enteropathy was proposed, and he was started on iron supplements and switched to a soy formula. At age 3 years failure to thrive was evident. A small bowel follow-through showed slightly edematous folds of the proximal jejunum. Despite the soy formula hypoalbuminemia $(29 \mathrm{~g} / \mathrm{L})$ and occult blood loss in his stools persisted. At that time a small bowel biopsy was performed but no abnormality was detected. Results from a $72 \mathrm{~h}$ stool collection for fat were normal. Caloric intake was low. By age 3 years his calorie count was evaluated at $610 \mathrm{cal} /$ day; caloric needs for that age are $1400 \mathrm{cal} /$ day.

At age 3.5 a chromium-labelled albumin excretion test in stools confirmed protein losing enteropathy $(5.2 \%$ excretion of ${ }^{51} \mathrm{Cr}$ albumin, nitrogen $2 \%$ ). A $24 \mathrm{~h}$ urine collection demonstrated normal proteinuria. Barium enema performed at age 3 years 5 months was normal. The terminal ileum was nodular (nodularity thought to be from lymphoid nodular hyperplasia).

Because his condition remained unchanged at age 3 years 10 months he underwent an exploratory laparotomy to search for a Meckel's diverticulum or another source of gastrointestinal bleeding. The terminal ileum was identified, and the entire small bowel eviscerated through the wound. No Meckel's diverticulum was found. The serosal surfaces of the bowel appeared normal, and there was no evidence of mesenteric disease. The colon appeared to be perfectly normal on inspection and palpation. However, the small bowel had mucosal nodules, one of which was biopsed and appeared to consist of lymphoid hyperplasia with a significant amount of eosinophils.

At age 4 years eight months he was admitted for initiation of an elimination diet which consisted of a no gluten, bovine products, soy and eggs. His bone age was delayed at three years and his serum albumin was still low ( $29 \mathrm{~g} / \mathrm{L})$. No clinical or biochemical improvement was noted.

At age 9 years 5 months corticotherapy was recommended to the parents but not instituted. On reevaluation, anemia (hemoglobin $102 \mathrm{~g} / \mathrm{L}$, mean cell volume $69 \mathrm{fL}$ ), hypoalbuminemia $(20 \mathrm{~g} / \mathrm{L})$ and occult blood positive stools were all present. His bone age was significantly delayed (age 6.5 to 7 years).

Since initial presentation the patient had little to no gastrointestinal symptoms. The patient had no diarrhea, no nausea and no vomiting. Abdominal pains were also never a major complaint; they were noted at age 4 as being bilateral lower abdominal pains on and off. Thus, the patient's major problem was severe failure to thrive, chronic anemia and hypoalbuminemia. Immune work-up over these years included normal immunoglobulins (A, E, D, M, G), normal B and $\mathrm{T}$ lymphocyte count, and positive skin tests for milk, beef, peanut and egg white. Endocrine work-up showed normal cortisol, insulin, thyroxine and thyroid-stimulating hormone. A barium enema double contrast was repeated at age 9 and showed no signs of inflammatory bowel disease (the examination was normal).

At age 11 years 9 months he presented with epigastric pain and abdominal guarding following a kick to his abdomen. Abdominal $\mathrm{x}$-ray showed free air with perforated viscus. Preoperative hemoglobin was $83 \mathrm{~g} / \mathrm{L}$. Surgical exploration revealed a perforation at the pyloroduodenal junction, which was repaired with a Graham patch. The perforation measured $5 \mathrm{~mm}$ and was surrounded by edematous and fibrotic inflammatory tissue. The initial impression was that of a chronic pyloric duodenal bulb ulcer with perforation. There was also a thickened mass of bowel surrounded by diffuse purulent peritonitis. No biopsies were performed. No postoperative complications were noted, and he was discharged with cimetidine.

Six weeks later an upper endoscopy revealed a deformed pylorus with erythema of the antrum and peripyloric area, and an edematous and hyperhemic duodenal bulb with a scar noted in the duodenal bulb.

Endoscopic biopsies from the antrum (Figure 1) and duo- 


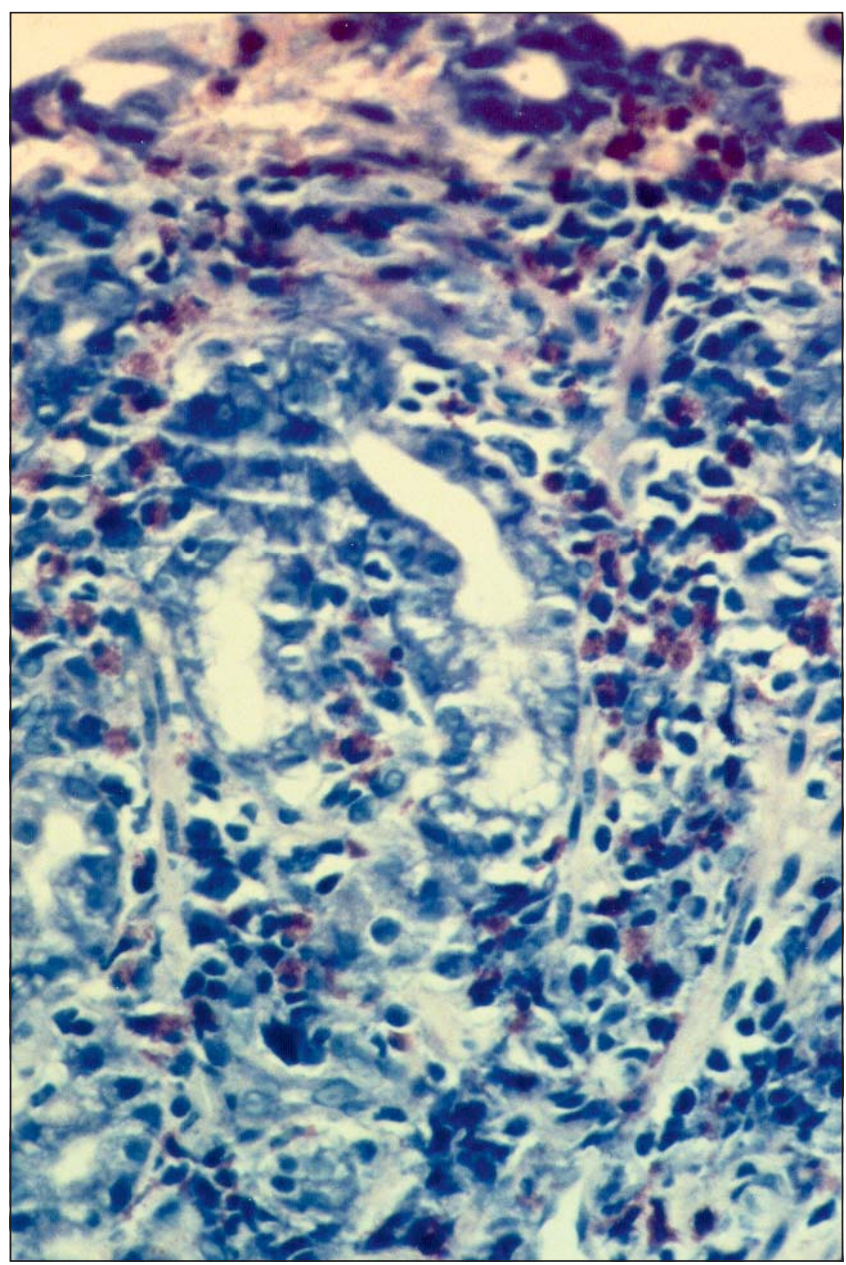

Figure 1) Endoscopic antral biopsy from patient six weeks after surgery for perforated duodenal ulcer. Fairly dense eosinophilic infiltrate of the lamina propria is noted

denal bulb revealed similar histological changes characterized by a fairly dense, primarily eosinophilic, infiltrate in the lamina propria, with focal invasion of crypt and surface epithelium. Helicobacter pylori was not seen on hematoxylin, phloxine and saffron stain nor on Giemsa stain. No ulceration or microabscesses were seen, although in one biopsy focal inflammatory atypia of crypt epithelium and the presence of an eosinophil-rich inflammatory exudate overlying the mucosa were noted.

Corticotherapy was instituted at $2 \mathrm{mg} / \mathrm{kg} / \mathrm{day}$. Two months later an upper endoscopy was repeated, mainly to reevaluate the cell atypia described previously. Repeat duodenal and antral biopsies showed partial resolution of the eosinophilic infiltrates, and the atypia was no longer present.

At age 12.5 years he presented with lower gastrointestinal bleeding and a hemoglobin of $98 \mathrm{~g} / \mathrm{L}$, compared with $118 \mathrm{~g} / \mathrm{L}$ three months before. Repeat upper endoscopy revealed two duodenal ulcers, biopsies of which confirmed the presence of a preeminent eosinophilia in the lamina propria. He remained on prednisone $10 \mathrm{mg}$ every other day and restarted cimetidine. A month later albumin decreased to $30 \mathrm{~g} / \mathrm{L}$ and hemoglobin decreased to $85 \mathrm{~g} / \mathrm{L}$ (hemoglobin was $102 \mathrm{~g} / \mathrm{L}$ the previous month). He was restarted on $40 \mathrm{mg} /$ day oral prednisone and slowly weaned. He remained steroid-dependent.

By age 14 years 7 months supplemental nocturnal enteral feedings by nasogastric infusion were finally accepted by the patient and his family to treat his growth failure. In the interim he remained steroid-dependent and required prednisone (15 mg orally every other day). At admission, an upper gastrointestinal and small bowel follow-through showed an irregular duodenal bulb suggestive of scarring. The rest of the examination was normal, specifically the terminal ileum. There was no evidence of thickening folds.

Very poor caloric intake had been a consistent problem. Nocturnal enteral feedings (Isosource; Sandoz Nutrition) resulted initially in a tremendous weight gain. His anemia resolved (hemoglobin $121 \mathrm{~g} / \mathrm{L}$ ), albumin normalized ( $36 \mathrm{~g} / \mathrm{L}$ ) and growth improved dramatically. Off nasogastric feedings his weight plateaued. Our patient's final height is $152.5 \mathrm{~cm}$ at age 20 . His height age is 12.5 years. His genetic potential was evaluated at $160.2 \pm 8.5 \mathrm{~cm}$ as assessed according to his parents' height.

\section{DISCUSSION}

Since its initial description by Kaijser in 1937 (1), EGE has been widely assumed to be an allergic or immunological disorder. Its pathophysiology, however, remains unknown. Although EGE is often regarded as allergic in origin, trials of elimination diet generally have been unsuccessful. Less than half of all patients described with EGE have a personal or family history of atopy (10). In EGE patients there is no global alteration of immune status (12). Some patients may have an increase in total serum immunoglobulin $\mathrm{E}$, with immunoglobulin E antibodies specific to food antigens (13). Although elimination diet is usually given a trial, rarely will there be a clinical improvement, irrespective of skin test results. Leinbach and Rubin (14) found the results of skin testing in these patients to correlate poorly with their symptoms.

EGE may be found throughout the gastrointestinal tract. The stomach is commonly involved, but the esophagus and colon are usually spared (7). As with Crohn's disease, the lesions are focal, and the tissue as well as peripheral eosinophilia may fluctuate, sometimes making the diagnosis difficult. As documented by Hoefer et al (7), localization differs between child and adult patients. Adults reportedly have stomach and small bowel involved in $52.1 \%$ and $40.8 \%$ of cases, respectively, whereas in children the involvement was $25.9 \%$ and $66.7 \%$, respectively. In both age groups, the colon tends to be the least involved portion of the gastrointestinal tract. In the pediatric population there is heavy male preponderance, contrasting sharply with adults where sexual distribution is equal (7).

Gastric involvement is usually limited to the antrum or distal half of stomach and occurs with pyloric obstruction, a known complication $(12,15)$. The antral biopsy $(10-17)$ is usually accepted as the preferred site of biopsy for diagnosis in the majority of reported pediatric cases. Tissue eosino- 
TABLE 2

Previous reported cases of eosinophilic gastroenteritis (EGE) with perforation of the gastrointestinal tract

\begin{tabular}{|c|c|c|c|c|c|}
\hline Reference & $\begin{array}{c}\text { Age } \\
\text { (years) }\end{array}$ & Sex & $\begin{array}{l}\text { Level of gastrointestinal } \\
\text { perforation }\end{array}$ & Gastrointestinal complaints ${ }^{\star}$ & History of allergy \\
\hline Russell et al (24) & 45 & Male & Duodenum & Recent onset upper abdominal discomfort & Contact dermatitis \\
\hline Hoefer et al (7) & 6 & Male & Distal ileum & $\begin{array}{l}\text { Recurrent abdominal pain, nausea, } \\
\text { vomiting, diarrhea }\end{array}$ & Negative \\
\hline Felt-Bersma et al (25) & 74 & Female & $\begin{array}{l}\text { Small bowel }(90 \mathrm{~cm} \text { distal to } \\
\text { ligament of Treitz) }\end{array}$ & $\begin{array}{l}\text { Several years: low body weight, frequent } \\
\text { loose stools }\end{array}$ & Occasional pruritus \\
\hline Lysey et al (26) & 45 & Female & $\begin{array}{l}\text { Small bowel }(100 \mathrm{~cm} \\
\text { proximal to ileocecal } \\
\text { valve })\end{array}$ & $\begin{array}{l}\text { Recurrent right lower quadrant pains, } \\
\text { vomiting, diarrhea, weight loss over } \\
\text { three months }\end{array}$ & $\begin{array}{l}\text { Recurrent generalized } \\
\text { urticaria in } \\
\text { childhood }\end{array}$ \\
\hline Walia et al (27) & 60 & Female & Proximal small bowel & & Negative \\
\hline Wang et al (28) & 60 & Male & Small bowel & Perforation while on corticotherapy for EGE & Negative \\
\hline
\end{tabular}

${ }^{*}$ Before onset of symptoms in relation to gut perforation

philia may be focal, necessitating multiple biopsies for confirmation of the diagnosis (10). Pathologically, the local eosinophilic infiltrates are often associated with tissue edema, shortening of villi, epithelial necrosis and peripheral eosinophilia $(8,9,17)$.

EGE is nearly always limited to the gut but involvement of other organs, including the liver (18), gallbladder, spleen, bladder $(19,20)$ and pancreas $(21)$, has been reported in adults. Thus, the clinical presentation of EGE depends on the primary site of involvement (16). Patients with mucosal disease present with intermittent nausea, vomiting, abdominal pain and diarrhea. Bleeding is occasionally seen. When severe disease is present weight loss or edema from proteinlosing enteropathy may predominate. Symptoms may be correlated with ingestion of certain foods. In EGE involving the muscularis, intestinal obstruction is a frequent presentation, most often in the distal stomach. In EGE's serosal form $(22,23)$ ascites containing a high eosinophil count is noted. When the inflammation is transmural, pain, perforation, obstruction, bleeding or fistulas may be seen. However, free bowel perforation is, in fact, a very rare complication of EGE.

The majority of reported pediatric cases have involvement predominantly of the muscular layer. Subserol disease appears least associated with historical and immunochemical evidence of allergy, while mucosal layer disease may have an allergic basis (15).

We found only six other cases in the adult and pediatric literature with perforation of the gastrointestinal tract in EGE, all of which had more than our bowel layer involved $(7,24-28)$ (Table 2). The only other pediatric patient was reported by Hoefer et al in 1977 (7). That patient presented with perforation of the antimesenteric ileum. Pathology confirmed ileal EGE. Fifteen months after surgical repair that patient presented again with distal ileal perforation. Further treatment was not necessary.

Our patient presented with long-lasting malabsorptive disease. Celiac disease was excluded by a normal D-xylose test and, furthermore, a normal small bowel biopsy. Inflammatory bowel disease with onset in infancy could have been possible. Repeat gastrointestinal tract imaging failed to demonstrate any abnormalities (upper gastrointestinal tract, small bowel follow-through, barium enema). A colonoscopy was never obtained but the patient never presented 'colitic' type of symptoms. Cystic fibrosis was excluded by a normal sweat test. No steatorrhea was demonstrated. Chronic parasitic infestations, particulary giardiasis, were not demonstrated by either stool examinations or endoscopic biopsies of the duodenum. Gastritis due to H pylori is also in the differential diagnosis. However, no histological evidence of $\mathrm{H} p y$ lori was observed, and the predominantly eosinophilic nature of the infiltrates is most uncharacteristic of $H$ pylori gastritis.

Our patient's EGE was a transmural disease of the gastrointestinal tract, which appeared to not affect other digestive organs. He did not respond to elimination diet. Food allergy did not appear to be a contributory factor. The dominating symptoms throughout his life were severe failure to thrive accompanied by delayed bone maturation, hypoalbuminemia from protein-losing enteropathy, iron-deficient anemia and intermittent eosinophilia.

\section{CONCLUSIONS}

Free bowel perforation is, thus, a very rare complication of EGE. Only one other pediatric patient has been reported in the literature with such a complication. In our case, a long term malabsorptive state dominated the clinical picture and was associated with failure to thrive. Our patient's severe transmural disease also led to perforation of his gastrointestinal tract. Various elimination diets were unsuccessful. Corticosteroid therapy combined with supplemental nocturnal enteral feedings helped to control his severe disease.

\section{REFERENCES}

1. Kaijser R. Zur Kenntnis derailer gischen affektionen des verdaungskanal vom stand punkt des chirurgen aus. Arch Klin Chir 1937;188:36-64.

2. Zora JA, O'Connell EJ, Sachs MI, Hoffman AD. Eosinophilic gastroenteritis: A case report and review of the literature. Ann Allergy 1984;53:45-7.

3. Kravis LP, South MA, Rosenlund ML. Eosinophilic gastroenteritis in the pediatric patient. Clinical Pediatrics 1982;21:713-7.

4. Zona JZ, Belin RP, Burke JA. Eosinophilic infiltration of the gastrointestinal tract in children. Am J Dis Child 1976;130:1136-9.

5. Cello JP. Eosinophilic gastroenteritis. A complex disease entity. Am J Med 1979;67:1097-104.

6. Whitington PF, Whitington GL. Eosinophilic gastroenteropathy in childhood. J Pediatr Gastroenterol Nutr 1988;7:379-85.

7. Hoefer Ra, Ziegler MM, Koop CE, Schnaufer L. Surgical 
manifestations of eosinophilic gastroenteritis in the pediatric patient. J Pediatr Surg 1977;12:955-62.

8. Blackshaw AJ, Levison DA. Eosinophilic infiltrates of the gastrointestinal tract. J Clin Pathol 1986;39:1-7.

9. Johnstone JM, Morson BC. Eosinophilic gastroenteritis. Histopathology 1978;2:335-48.

10. Goldman H, Proujansky R. Allergic proctitis and gastroenteritis in children: Clinical and mucosal biopsy features in 53 cases. Am J Surg Pathol 1986;10:75-86.

11. Klein NC, Hargrove RL, Sleisenger MH, Jeffries GH. Eosinophilic gastroenteritis. Medicine (Baltimore) 1970;49:299-319.

12. Caldwell JH, Mekhjian HS, Hurtubise PE, Beman FM. Eosinophilic gastroenteritis with obstruction: Immunological studies of seven patients. Gastroenterology 1978;74:825-8.

13. Caldwell JH, Tennembaum JI, Bronstein HA. Serum IgE in eosinophilic gastroenteritis: Response to intestinal challenge in two cases. N Engl J Med 1975;292:1388-90.

14. Leinbach GE, Rubin CE. Eosinophilic gastroenteritis: A simple reaction to food allergens? Gastroenterology 1970;59:874-89.

15. Snyder JD, Rosenblum N, Wershil B, Goldman H, Winter M. Pyloric stenosis and eosinophilic gastroenteritis in infants. J Pediatr Gastroenterol Nutr 1987;6:543-7.

16. Talley NJ, Shorter RG, Phillips SF, Zinsweister AR. Eosinophilic gastroenteritis: a clinicopathological study of patients with disease of the mucosa, muscle layer and subserosal tissues. Gut 1990;31:54-8.

17. Katz AJ, Goldman H, Grand RJ. Gastric mucosal biopsy in eosinophilic (allergic) gastroenteritis. Gastroenterology 1977;73:705-9
18. Everett GD, Mitros FA. Eosinophilic gastroenteritis with hepatic eosinophilic granulomas. Clinical vignette. Am J Gastroenterol $1980 ; 74: 519-21$

19. Peterson NE, Silverman A, Campbell JB. Eosinophilic cystitis and coexistent eosinophilic gastroenteritis in an infant. Pediatr Radiol 1989;19:484-5.

20. Gregg JA, Utz DC. Eosinophilic cystitis associated with eosinophilic gastroenteritis. Mayo Clinic Proc 1974;49:185-7.

21. Rodriguez AL. Pancreatitis and eosinophilic gastroenteritis. Int Surg 1973;58:415-9.

22. Hyams JS, Treeur WR, Schwartz AN. Recurrent abdominal pain and ascites in an adolescent. J Pediatr 1988;113:569-74.

23. McNabb PC, Fleming CR, Higgins JA, Davis GL. Transmural eosinophilic gastroenteritis with ascites. Mayo Clin Proc 1979;54:119-22.

24. Russell JY, Evangelou G. Eosinophilic infiltration of the stomach and duodenum complicated by perforation. Postgrad Med 1965;41:30-3.

25. Felt-Bersma RJ, Meuwissen SG, Van Velzen D. Perforation of the small intestine due to eosinophilic gastroenteritis. Am J Gastroenterol 1984;79:442-5.

26. Lysey J, Eid A, Schuger L. Eosinophilic gastroenteritis with small bowel perforation. J Clin Gastroenterol 1986;8:694-5. (Lett)

27. Walia HS, Abraham TK, Walia H. Eosinophilic enteritis with perforation. Can J Surg 1988;31:268.

28. Wang C-S, Hsueh S, Shih LY, Chen MF. Repeated bowel resections for eosinophilic gastroenteritis with obstruction and perforation. Acta Chir Scand 1990;156:333-6. 


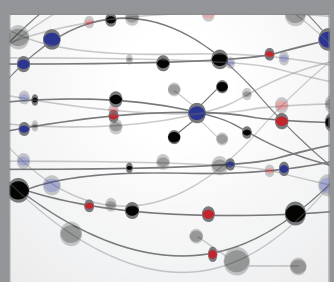

The Scientific World Journal
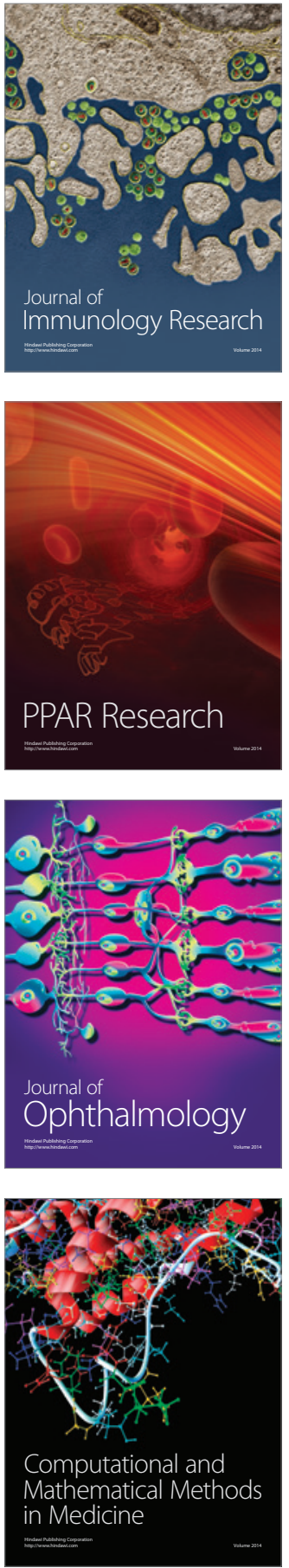

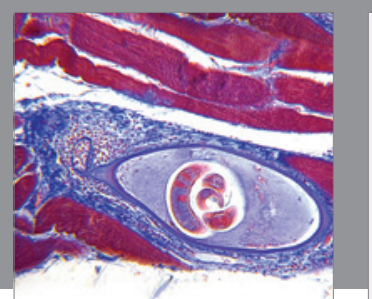

Gastroenterology Research and Practice

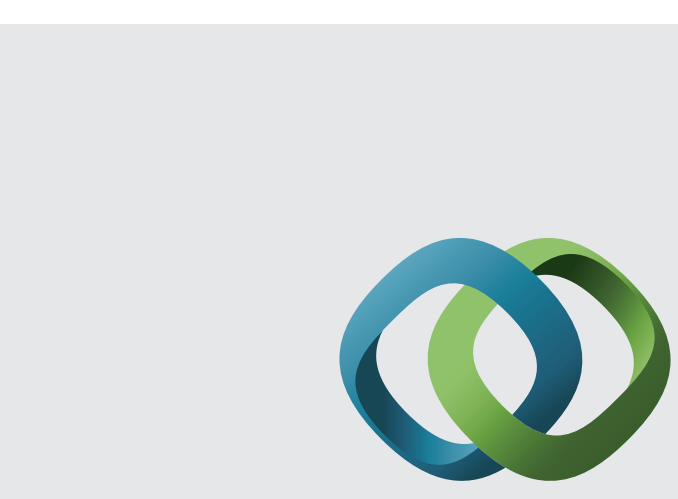

\section{Hindawi}

Submit your manuscripts at

http://www.hindawi.com
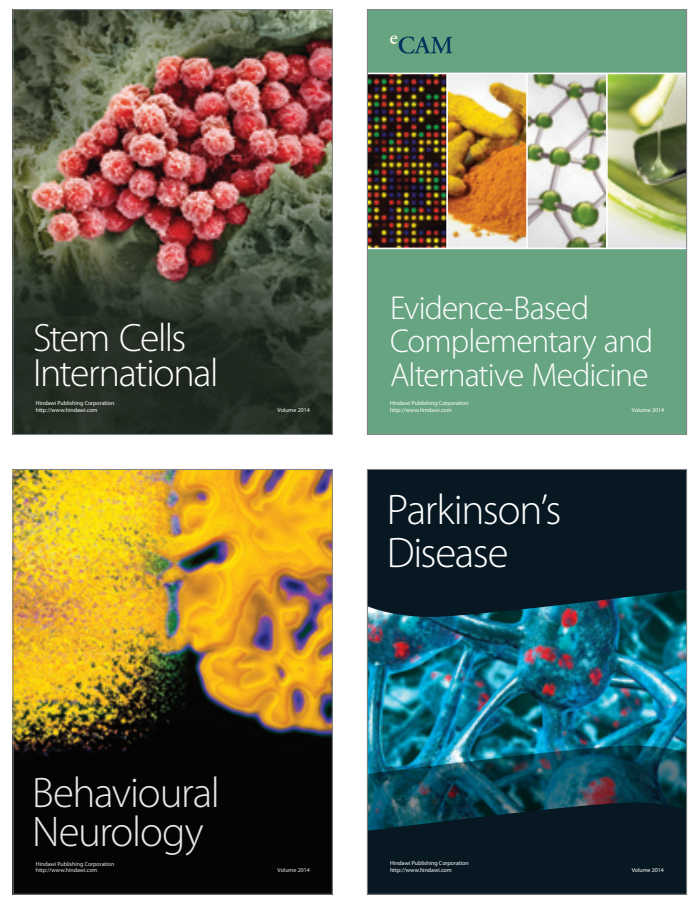
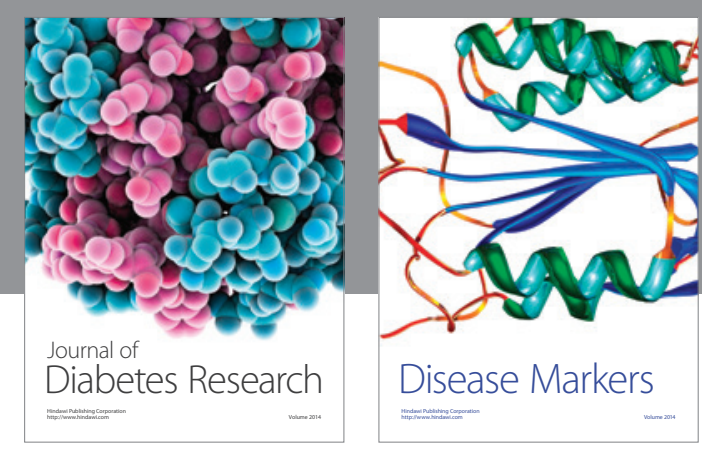

Disease Markers
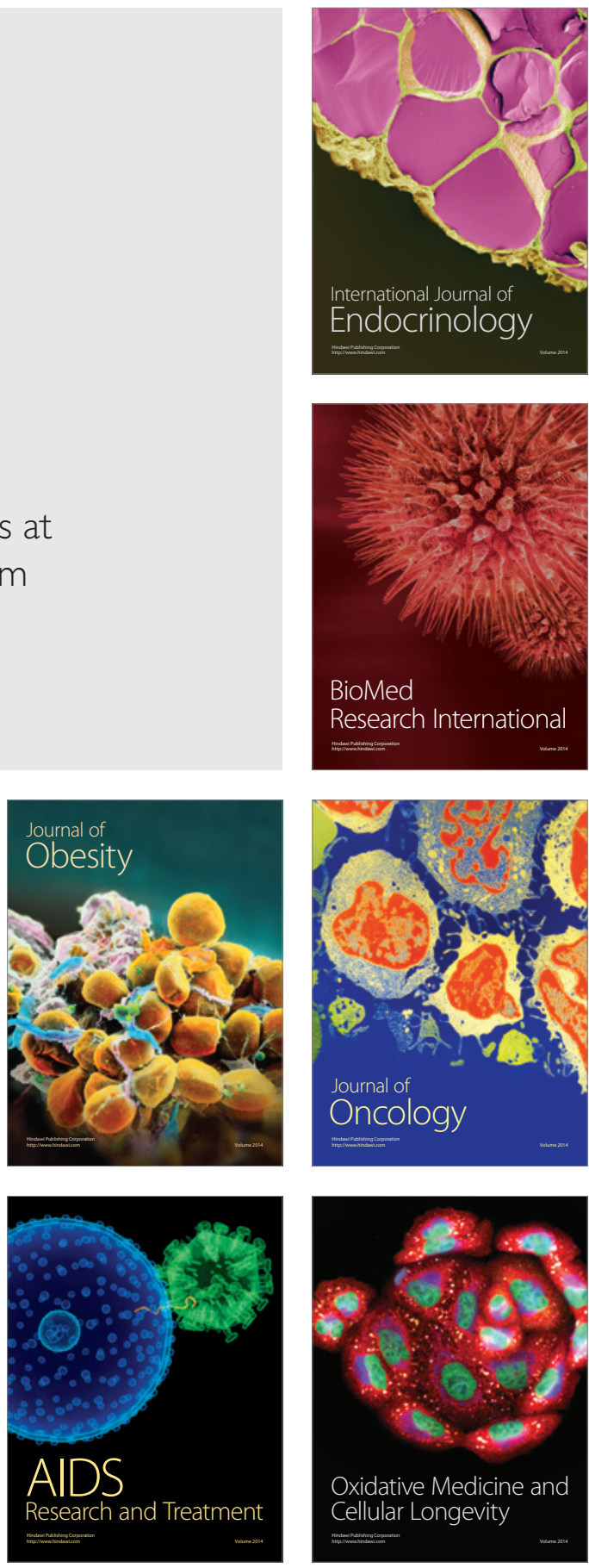